\title{
Cotton Crop Management Practices Adopted in a Tribal Region of Odisha
}

\author{
Chitrasena Padhy ${ }^{1 *}$, Pakalpati Satyanarayana Raju ${ }^{2}$ and Rabindra Kumar Raj ${ }^{3}$ \\ ${ }^{1}$ Agricultural Extension, ${ }^{2}$ Department of Agronomy, M.S. Swaminathan School of Agriculture, \\ Centurion University of Technology and Management, Odisha, India \\ ${ }^{3}$ Agricultural Extension and Communication, Institute of Agricultural Science, SOADU, \\ Bhubaneswar, Odisha, India \\ *Corresponding author
}

\section{A B S T R A C T}

Keywords

Cotton, Crop cultivars, Crop management, Crop yields, Extension officials

\section{Article Info}

Accepted:

12 December 2020

Available Online:

10 January 2021
The farmers in the tribal districts of Gajapati and Rayagada have been cultivating cotton as a commercial crop over the years to support their livelihood. Adoption of appropriate crop management practices helps to minimize the deletorious effects of production factors and leads to improvement in cotton yields. A study was undertaken on 240 cotton growers from four blocks of the two districts. Data was collected personally on the extent of adoption of standard crop management practices through a semi-structured schedule and analysed using appropriate statistical methods. It was observed that the respondents largely adopted the basic cotton cultivation practices recommended. However, deficiencies were observed in levelling, sub-plotting, bunding, adoption of appropriate crop cultivars, application of recommended dose of manures and fertilisers based on soil test, delinting and treatment of seeds, sowing in paired rows, drilling two seeds per pit, $3^{\text {rd }}$ weeding, hoeing and earthing-up at six weeks, hormone application, plant protection measures after 110 days of sowing, picking bolls in the cool hours of morning, picking at $50 \%$ bursting of bolls, and avoiding admixtures of leaves. Extension contact, house type, social participation, annual income, farming experience, and aptitude of the respondents significantly influenced adoption of recommended crop management practices. The agricultural extension officials promoting cotton cultivation in these districts have to analyse these factors and take appropriate measures to enrich the knowledge and skills of cotton farmers to enable them to adopt suitable crop management practices to generate more income.

\section{Introduction}

Cotton occupies a predominant position in Indian economy by generating direct and indirect employment in the agricultural and industrial sectors. It provides livelihood for about 250 million people in India through cultivation, trade, and textile industries (Rajeswar et al., 2019). Sustainability of cotton production relies on achieving high yields through precise water, nutrition, and crop growth management (Cetin and Basbag, 2010). In addition, fruiting of cotton plant is determined and influenced by cultivars, 
climatic conditions, and crop management practices including control of insect pests and diseases. Environmental factors such as rainfall, evaporation, humidity, sunshine duration, and surface soil temperature significantly affect flower and boll production (Sawan et al., 2002). Adoption of appropriate cultural practices helps to minimize the deleterious effects of these factors and leads to improvement in cotton yields (Sawan, 2009). Therefore, cotton farmers have to adopt suitable crop management practices for sustainable crop production with reduced cost and increased yield and minimize health risks and environmental damage by reducing the use of chemical fertilizers and pesitcides as well as by better use of natural resources such as water and soil nutrients (Padwal et al., 2018). This study was therefore undertaken to assess the crop management practices adopted by the farmers in two cotton growing districts of Odisha.

\section{Materials and Methods}

The study was undertaken in the tribal regions of Odisha, India. Two tribal dominated districts, viz. Gajapati and Rayagada, having cotton cultivation were selected. Rayagada and Kashinagar blocks in Gajapati district as well as Gunupur and Ramanaguda blocks in Rayagada district were randomly selected. Similarly, four panchayats in each block, viz. Sanatundi, Kumelsingha, Karadasingi, and Rayagada in Rayagada block, and Budura, Khandaba, Alada, and Goribandha in Kashinagar block, Gadhikhala, Sirijholi, Chalkamba, and Jaganathpur in Gunupur block as well as Buting, Nilamguda, Bhamini, and Golumunda in Ramanaguda block were randomly selected. Around $15 \%$ of the farmers cultivating cotton from all these panchayats were also selected randomly. Thus, 67 farmers from Rayagada, 53 from Kashinagar, 62 from Gunupur, and 58 from Ramanaguda blocks were selected randomly as respondents for the study with the total sample size being 240 .

The data was collected personally through a semi-structured schedule after pretesting. Data was collected from the farmers on the extent of adoption of standard crop management practices of land preparation, sowing, delinting seed treatment prior to sowing, manure and fertilizer applications, intercultural operations, plant protection, and harvest and post-harvest operations. The data was collected on the scale point of fully, partially, and not adopted on various aspects of crop management practices and were analysed with the score values of 3,2 and 1, respectively. Statistical tools such as mean score, gap percentage, rank order, and path analysis were employed to deduce the results.

\section{Results and Discussion}

A fine seed bed is essential for securing a good plant stand. Summer and deep ploughing and well pulverised soil with clean and friable seed bed are recommended in land preparation. It was observed that the respondents adopted 3 to 4 summer ploughings, deep ploughing at $15-20 \mathrm{~cm}$ depth, planking after each ploughing, choosing soil with good water holding capacity, good aeration with no water logging, and high in organic matter content, as well as preparing clean, friable, and well pulverized seed bed (Table-1). The findings therefore revealed that the respondents in general adopted most of the recommended practices in land preparation.

Early sowing ensures good harvest. In southern Odisha, cotton is recommended to be sown in the month of June immediately following the onset of monsoon to evade disease and insect pest attack. Analysis of data revealed that (Table-2) the respondents adopted the recommended practices of sowing in June at the onset of monsoon and sowing in 
single rows. The respondents sowed hybrid seeds that were available in the market and raised additional seeds in leaf bags to be used later for gap filling to maintain optimum plant spacing. Poor adoption of recommended practices were observed while using Bunny, American, and Indian cotton varieties, sowing in double rows, sowing two seeds per pit, and sowing seeds by drilling. It is apprehended that the respondents had little knowledge about the crop varieties, advantage of sowing in double rows for better yields, sowing two seeds per pit as a safety measure against poor germination, and sowing seeds by drilling for better soil coverage.

Delinting of cotton seeds is essential for good germination. The seeds are treated with sulphuric acid followed by thorough washing. Poor adoption of seed delinting treatment practices by the respondents was observed (Table-3). Though the farmers positively responded for sowing delinted seeds and soaking in water for 10-12 hours, poor adoption of the practice of delinting was observed while soaking seed in sulphuric acid for two minutes, washing in running water, and drying under shade before sowing.

Cotton crop responds well to nitrogenous fertiliser. Phosphorous and potassic fertilisers are also recommended. Split application and spraying of fertilisers is found to be beneficial. Soil test based fertiliser application is usually advocated for better crop growth and production. Hormone application at 45 and 60 days is essential at square and boll formation stage to check boll shedding. Spraying of $1.5 \%$ DAP at 70 and 90 days and $0.75 \%$ of both DAP and MOP at 105 days and spraying of urea 2-3 times at 10-day intervals 60 days after sowing is also recommended. But, the respondents were not following these practices indicating poor adoption. However, better adoption was observed on using recommended dose, basal application of phosphorous and potash as well as split application of nitrogenous fertiliser.

Table.1 Adoption of practices in land preparation

\begin{tabular}{|c|c|c|c|c|c|}
\hline \multirow{2}{*}{$\begin{array}{l}\text { Sl. } \\
\text { No. }\end{array}$} & \multirow[t]{2}{*}{ Practice } & \multicolumn{2}{|c|}{ Mean Score } & \multirow{2}{*}{$\begin{array}{l}\text { Pooled } \\
\text { Mean } \\
\text { Score } \\
(n=240)\end{array}$} & \multirow[t]{2}{*}{ Rank } \\
\hline & & $\begin{array}{l}\text { Gajapati } \\
\text { District }(n=120)\end{array}$ & $\begin{array}{l}\text { Rayagada } \\
\text { District }(\mathrm{n}=120)\end{array}$ & & \\
\hline 1 & 3-4 summer ploughings & 2.83 & 2.72 & 2.77 & 1 \\
\hline 2 & $\begin{array}{l}\text { Deep ploughing at } 15-20 \mathrm{~cm} \\
\text { depth }\end{array}$ & 2.47 & 2.46 & 2.46 & 7 \\
\hline 3 & Planking after each ploughing & 2.43 & 2.45 & 2.44 & 8 \\
\hline 4 & $\begin{array}{l}\text { Good water holding capacity } \\
\text { of soil }\end{array}$ & 2.57 & 2.57 & 2.57 & 4 \\
\hline 5 & $\begin{array}{l}\text { High organic matter content in } \\
\text { soil }\end{array}$ & 2.70 & 2.38 & 2.54 & 6 \\
\hline 6 & Good aeration in soil & 2.48 & 2.43 & 2.46 & 7 \\
\hline 7 & $\begin{array}{l}\text { Good surface drainage to } \\
\text { avoid waterlogging }\end{array}$ & 2.80 & 2.57 & 2.68 & 2 \\
\hline 8 & Preparing well pulverised soil & 2.62 & 2.49 & 2.55 & 5 \\
\hline 9 & $\begin{array}{l}\text { Maintaining clean and friable } \\
\text { seed bed }\end{array}$ & 2.69 & 2.55 & 2.62 & 3 \\
\hline
\end{tabular}

Maximum obtainable score: 3 
Table.2 Adoption of practices in sowing

\begin{tabular}{|l|l|l|l|l|l|}
\hline $\begin{array}{l}\text { Sl. } \\
\text { No. }\end{array}$ & \multicolumn{1}{|c|}{ Practice } & \multicolumn{2}{|c|}{ Mean Score } & $\begin{array}{l}\text { Pooled } \\
\text { Mean Score } \\
(\mathbf{n = 2 4 0})\end{array}$ & Rank \\
\cline { 4 - 6 } & $\begin{array}{l}\text { Gajapati } \\
\text { District } \\
(\mathbf{n = 1 2 0})\end{array}$ & $\begin{array}{l}\text { Rayagada } \\
\text { District } \\
(\mathbf{n = 1 2 0})\end{array}$ & 1.38 & 1.38 & 8 \\
\hline $\mathbf{1}$ & $\begin{array}{l}\text { Using seeds of Bunny, } \\
\text { American and Indian cotton }\end{array}$ & 1.38 & 2.68 & 2.78 & 2 \\
\hline $\mathbf{2}$ & $\begin{array}{l}\text { Hybrid variety available in the } \\
\text { market }\end{array}$ & 2.89 & 2.41 & 2.45 & 4 \\
\hline $\mathbf{3}$ & $\begin{array}{l}\text { Sowing immediately after onset } \\
\text { of monsoon }\end{array}$ & 2.49 & 2.96 & 2.89 & 1 \\
\hline $\mathbf{4}$ & Sowing in single rows & 2.83 & 1.13 & 1.18 & 9 \\
\hline $\mathbf{5}$ & Sowing in paired rows & 1.23 & 1.68 & 1.68 & 7 \\
\hline $\mathbf{6}$ & Sowing 2 seeds per pit & 1.67 & 1.83 & 1.90 & 6 \\
\hline $\mathbf{7}$ & $\begin{array}{l}\text { Sowing by drilling seeds in } \\
\text { rows }\end{array}$ & 1.97 & 2.76 & 2.76 & 3 \\
\hline $\mathbf{8}$ & Spacing of 90 x 90 cm & 2.77 & 2.33 & 2.38 & 5 \\
\hline $\mathbf{9}$ & $\begin{array}{l}\text { Raising additional seeds in leaf } \\
\text { bag for gap filling }\end{array}$ & 2.43 & & & \\
\hline
\end{tabular}

Maximum obtainable score: 3

Table.3 Adoption of practices in seed treatment

\begin{tabular}{|c|c|c|c|c|c|}
\hline \multirow{2}{*}{$\begin{array}{l}\text { Sl. } \\
\text { No. }\end{array}$} & \multirow[t]{2}{*}{ Practice } & \multicolumn{2}{|c|}{ Mean Score } & \multirow{2}{*}{$\begin{array}{l}\text { Pooled } \\
\text { Mean } \\
\text { Score } \\
(n=240)\end{array}$} & \multirow[t]{2}{*}{ Rank } \\
\hline & & $\begin{array}{l}\text { Gajapati } \\
\text { District } \\
(\mathbf{n}=120)\end{array}$ & $\begin{array}{l}\text { Rayagada } \\
\text { District } \\
(\mathbf{n}=120)\end{array}$ & & \\
\hline 1 & Sowing delinted seeds & 2.06 & 2.29 & 2.18 & 1 \\
\hline 2 & $\begin{array}{l}\text { Soaking seeds in water for } \\
10-12 \text { hours }\end{array}$ & 2.03 & 2.15 & 2.09 & 2 \\
\hline 3 & $\begin{array}{l}\text { Rubbing with fresh cow } \\
\text { dung and wood ash after } \\
\text { soaking }\end{array}$ & 1.63 & 1.66 & 1.65 & 5 \\
\hline 4 & $\begin{array}{llrr}\begin{array}{l}\text { Soaking } \\
\text { sulphuric }\end{array} & \text { acid } & 70-100 & \mathrm{ml} \\
\text { minutes } & & \text { for } & \text { two }\end{array}$ & 1.31 & 1.55 & 1.43 & 6 \\
\hline 5 & $\begin{array}{l}\text { Washing in running water } \\
\text { after soaking }\end{array}$ & 1.68 & 1.95 & 1.82 & 4 \\
\hline 6 & $\begin{array}{l}\text { Drying under shade before } \\
\text { sowing }\end{array}$ & 1.75 & 1.92 & 1.83 & 3 \\
\hline 7 & Not treating the seeds & 1.53 & 1.23 & 1.38 & 7 \\
\hline
\end{tabular}

Maximum obtainable score: 3 
Table.4 Adoption of practices in manure and fertiliser applications

\begin{tabular}{|c|c|c|c|c|c|}
\hline \multirow{2}{*}{$\begin{array}{l}\text { SI. } \\
\text { No. }\end{array}$} & \multirow[t]{2}{*}{ Practice } & \multicolumn{2}{|c|}{ Mean Score } & \multirow{2}{*}{$\begin{array}{l}\text { Pooled } \\
\text { Mean } \\
\text { Score } \\
(\mathbf{n}=240)\end{array}$} & \multirow[t]{2}{*}{ Rank } \\
\hline & & $\begin{array}{l}\text { Gajapati } \\
\text { District } \\
(n=120)\end{array}$ & $\begin{array}{l}\text { Rayagada } \\
\text { District } \\
(\mathbf{n}=120)\end{array}$ & & \\
\hline 1 & $\begin{array}{l}\text { Applying 4-5 tonnes of organic } \\
\text { manure/ ha }\end{array}$ & 1.91 & 2.05 & 1.98 & 8 \\
\hline 2 & Applying 120-60-60 NPK/ha & 2.59 & 2.62 & 2.60 & 3 \\
\hline 3 & All $\mathrm{P}$ and $\mathrm{K}$ applied as basal & 2.74 & 2.72 & 2.73 & 2 \\
\hline 4 & $25 \% \mathrm{~N}$ at 20 days stage & 2.81 & 2.88 & 2.85 & 1 \\
\hline 5 & $50 \% \mathrm{~N}$ at 45 days & 2.60 & 2.29 & 2.45 & 4 \\
\hline 6 & $\begin{array}{l}\text { Rest of } N \text { as } 2-3 \text { urea sprays at } 10- \\
\text { day intervals after } 60 \text { days }\end{array}$ & 2.06 & 2.09 & 2.08 & 6 \\
\hline 7 & Adopting soil test based fertiliser & 1.30 & 1.48 & 1.39 & 10 \\
\hline 8 & $\begin{array}{l}\text { Spraying } 1.5 \% \text { DAP at } 70 \text { and } 90 \\
\text { days after sowing }\end{array}$ & 2.28 & 2.10 & 2.19 & 5 \\
\hline 9 & $\begin{array}{l}\text { Spraying } 0.75 \% \text { of both DAP and } \\
\text { MOP at } 105 \text { days after sowing }\end{array}$ & 1.55 & 1.54 & 1.55 & 9 \\
\hline 10 & $\begin{array}{l}\text { Spraying hormone at } 45 \text { and } 60 \\
\text { days to check boll shedding }\end{array}$ & 1.96 & 2.12 & 2.04 & 7 \\
\hline
\end{tabular}

Maximum obtainable score: 3

Table.5 Adoption of practices in intercultural operations

\begin{tabular}{|c|c|c|c|c|c|}
\hline \multirow{2}{*}{$\begin{array}{l}\text { Sl. } \\
\text { No. }\end{array}$} & \multirow[t]{2}{*}{ Practice } & \multicolumn{2}{|c|}{ Mean Score } & \multirow{2}{*}{$\begin{array}{l}\text { Pooled } \\
\text { Mean Score } \\
(\mathbf{n}=240)\end{array}$} & \multirow[t]{2}{*}{ Rank } \\
\hline & & $\begin{array}{l}\text { Gajapati } \\
\text { District } \\
(\mathbf{n}=120)\end{array}$ & $\begin{array}{l}\text { Rayagada } \\
\text { District }(\mathrm{n}=120)\end{array}$ & & \\
\hline 1 & Bunding, levelling, and sub-plotting & 1.27 & 1.15 & 1.21 & 9 \\
\hline 2 & $\begin{array}{l}\text { First hoeing and thinning } 10-12 \text { days } \\
\text { after emergence }\end{array}$ & 2.23 & 2.38 & 2.31 & 5 \\
\hline 3 & $\begin{array}{l}\text { Gap filling with seeds raised in leaf } \\
\text { bags }\end{array}$ & 2.61 & 2.80 & 2.70 & 3 \\
\hline 4 & $\begin{array}{l}\text { Second weeding and hoeing during } \\
\text { third week }\end{array}$ & 2.70 & 2.90 & 2.80 & 2 \\
\hline 5 & $\begin{array}{l}\text { Third weeding, hoeing, and earthing- } \\
\text { up at } 6 \text { weeks }\end{array}$ & 1.83 & 1.57 & 1.70 & 8 \\
\hline 6 & $\begin{array}{l}\text { Keeping the crop weed- free up to } 30- \\
40 \text { days after sowing }\end{array}$ & 2.33 & 2.23 & 2.28 & 7 \\
\hline 7 & Drainage to prevent waterlogging & 2.53 & 2.30 & 2.42 & 4 \\
\hline 8 & Life saving irrigation during dry spell & 2.38 & 2.23 & 2.30 & 6 \\
\hline 9 & $\begin{array}{l}\text { Removing apical portion of the plant } \\
\text { at } 1 \mathrm{~m} \text { height to promote reproductive } \\
\text { branches }\end{array}$ & 2.94 & 2.94 & 2.94 & 1 \\
\hline
\end{tabular}

Maximum obtainable score: 3 
Table.6 Adoption of practices in plant protection

\begin{tabular}{|c|c|c|c|c|c|}
\hline \multirow{2}{*}{$\begin{array}{l}\text { Sl. } \\
\text { No. }\end{array}$} & \multirow[t]{2}{*}{ Practice } & \multicolumn{2}{|c|}{ Mean Score } & \multirow{2}{*}{$\begin{array}{l}\text { Pooled } \\
\text { Mean } \\
\text { Score } \\
(\mathbf{n}=\mathbf{2 4 0})\end{array}$} & \multirow[t]{2}{*}{ Rank } \\
\hline & & $\begin{array}{l}\text { Gajapati } \\
\text { District } \\
(\mathbf{n}=120)\end{array}$ & $\begin{array}{l}\text { Rayagada } \\
\text { District } \\
(\mathbf{n}=120)\end{array}$ & & \\
\hline 1 & $\begin{array}{l}1^{\text {st }} \text { spraying of chemicals } 2-3 \\
\text { weeks after sowing }\end{array}$ & 2.85 & 2.97 & 2.91 & 3 \\
\hline 2 & $2^{\text {nd }}$ spraying after $50-55$ days & 2.88 & 2.95 & 2.92 & 2 \\
\hline 3 & $3^{\text {rd }}$ spraying after70 days & 2.93 & 2.97 & 2.95 & 1 \\
\hline 4 & $4^{\text {th }}$ spraying after $80-95$ days & 2.74 & 2.88 & 2.81 & 4 \\
\hline 5 & $5^{\text {th }}$ spraying after 110 days & 2.08 & 2.23 & 2.16 & 5 \\
\hline 6 & $\begin{array}{l}\text { Mixing both insecticides and } \\
\text { fungicides in spraying }\end{array}$ & 1.54 & 1.39 & 1.47 & 6 \\
\hline
\end{tabular}

Maximum obtainable score: 3

Table.7 Adoption of practices at harvest and post-harvest

\begin{tabular}{|c|c|c|c|c|c|}
\hline \multirow[t]{2}{*}{ Sl. No. } & \multirow[t]{2}{*}{ Practice } & \multicolumn{2}{|c|}{ Mean Score } & \multirow{2}{*}{$\begin{array}{l}\text { Pooled } \\
\text { Mean } \\
\text { Score } \\
(\mathbf{n}=240)\end{array}$} & \multirow[t]{2}{*}{ Rank } \\
\hline & & $\begin{array}{l}\text { Gajapati } \\
\text { District } \\
(\mathbf{n}=120)\end{array}$ & $\begin{array}{l}\text { Rayagada } \\
\text { District } \\
(\mathbf{n}=120)\end{array}$ & & \\
\hline 1 & Ensuring moisture at boll bursting & 2.48 & 2.40 & 2.44 & 6 \\
\hline 2 & $\begin{array}{l}\text { Picking when } 50 \% \text { bolls were } \\
\text { bursting }\end{array}$ & 2.10 & 2.15 & 2.13 & 9 \\
\hline 3 & Picking bolls by hand & 2.72 & 2.76 & 2.74 & 2 \\
\hline 4 & 4-5 pickings within 50 days & 2.47 & 2.18 & 2.33 & 8 \\
\hline 5 & Picking only fully burst open bolls & 2.84 & 2.69 & 2.77 & 1 \\
\hline 6 & $\begin{array}{l}\text { Picking bolls during cool hours of } \\
\text { morning }\end{array}$ & 1.90 & 1.78 & 1.84 & 11 \\
\hline 7 & Avoid admixture of leaves & 2.05 & 2.09 & 2.07 & 10 \\
\hline 8 & $\begin{array}{l}\text { Spreading bolls in sun for } 2-4 \text { hours } \\
\text { to dry }\end{array}$ & 2.63 & 2.63 & 2.63 & 4 \\
\hline 9 & $\begin{array}{l}\text { Not keeping picked cotton bolls in } \\
\text { wet channels in the field }\end{array}$ & 2.39 & 2.45 & 2.42 & 7 \\
\hline 10 & $\begin{array}{l}\text { Uprooting plant after last picking } \\
\text { and burying to kill insect pests and } \\
\text { disease pathogens }\end{array}$ & 2.56 & 2.43 & 2.49 & 5 \\
\hline 11 & $\begin{array}{l}\text { Ploughing the field to incorporate } \\
\text { debris into soil }\end{array}$ & 2.68 & 2.63 & 2.66 & 3 \\
\hline
\end{tabular}

Maximum obtainable score: 3 
Table.8 Path analysis of attributes influencing adoption of practices $(n=240)$

\begin{tabular}{|c|c|c|c|c|c|c|c|}
\hline \multirow{2}{*}{$\begin{array}{l}\text { Sl. } \\
\text { No. }\end{array}$} & \multirow[t]{2}{*}{ Attribute } & \multirow{2}{*}{$\begin{array}{l}\text { Total } \\
\text { effect }\end{array}$} & \multirow{2}{*}{$\begin{array}{l}\text { Total } \\
\text { direct } \\
\text { effect }\end{array}$} & \multirow{2}{*}{$\begin{array}{l}\text { Total } \\
\text { indirect } \\
\text { effect }\end{array}$} & \multicolumn{3}{|c|}{ Substantial effect } \\
\hline & & & & & I & II & III \\
\hline $\mathbf{X}_{1}$ & Age & 0.035 & 0.004 & 0.031 & $0.159 \mathrm{x}_{6}$ & $0.137 \mathrm{x}_{12}$ & $-0.055 \mathrm{x}_{2}$ \\
\hline $\mathbf{X}_{2}$ & Education & 0.115 & 0.071 & 0.044 & $0.162 \mathrm{x}_{5}$ & $0.120 \mathrm{x}_{14}$ & $0.038 \mathrm{x}_{11}$ \\
\hline $\mathbf{X}_{\mathbf{3}}$ & Holding size & 0.109 & 0.048 & 0.061 & $0.142 \mathrm{x}_{12}$ & $0.086 \mathrm{x}_{15}$ & $0.041 \mathrm{x}_{4}$ \\
\hline $\mathbf{X}_{4}$ & Farming experience & 0.064 & -0.016 & 0.080 & $-0.178 \mathrm{x}_{6}$ & $0.113 \mathrm{x}_{6}$ & $-0.071 x_{8}$ \\
\hline $\mathbf{X}_{5}$ & Caste & -0.051 & -0.112 & 0.061 & $-0.206 \mathrm{x}_{1}$ & $-0.167 x_{9}$ & $0.088 \mathrm{x}_{13}$ \\
\hline$X_{6}$ & Social participation & 0.137 & 0.097 & 0.040 & $-0.223 x_{1}$ & $-0.172 x_{8}$ & $0.074 \mathrm{x}_{6}$ \\
\hline $\mathbf{X}_{7}$ & Cosmopoliteness & 0.180 & 0.190 & 0.002 & $0.081 \mathrm{x}_{14}$ & $0.077 \mathrm{x}_{7}$ & $0.062 \mathrm{x}_{15}$ \\
\hline $\mathbf{X}_{8}$ & Extension contact & 0.002 & -0.178 & 0.192 & $0.195 \mathrm{x}_{13}$ & $0.114 \mathrm{x}_{12}$ & $0.023 \mathrm{x}_{8}$ \\
\hline$X_{9}$ & Source of information & 0.120 & -0.013 & 0.133 & $-0.256 \mathrm{x}_{2}$ & $0.186 \mathrm{x}_{3}$ & $-0.042 x_{9}$ \\
\hline$X_{10}$ & House type & 0.171 & 0.170 & 0.001 & $0.165 \mathrm{x}_{8}$ & $0.115 \mathrm{x}_{4}$ & $0.058 \mathrm{x}_{15}$ \\
\hline$X_{11}$ & Occupation & -0.030 & -0.046 & 0.016 & $-0.206 x_{7}$ & $0.167 \mathrm{x}_{9}$ & $0.088 \mathrm{x}_{13}$ \\
\hline$X_{12}$ & Annual income & 0.058 & -0.005 & 0.063 & $0.223 \mathrm{x}_{5}$ & $0.172 \mathrm{x}_{8}$ & $-0.074 \mathrm{x}_{7}$ \\
\hline$X_{13}$ & Social aptitude & 0.133 & 0.027 & 0.106 & $0.181 \mathrm{x}_{11}$ & $0.117 \mathrm{x}_{7}$ & $-0.062 x_{6}$ \\
\hline $\mathbf{X}_{14}$ & Economic aptitude & 0.178 & 0.110 & 0.068 & $-0.256 \mathrm{x}_{8}$ & $0.186 x_{13}$ & $-0.042 x_{9}$ \\
\hline$X_{15}$ & Scientific orientation & 0.139 & -0.017 & 0.156 & $0.144 \mathrm{x}_{6}$ & $-0.105 \mathrm{x}_{4}$ & $0.042 \mathrm{x}_{10}$ \\
\hline
\end{tabular}

Residual effect: 0.033

Highest indirect effect: Extension contact

Intercultural operations, particularly weeding, hoeing, earthing-up, drainage channelling, levelling, sub-plotting and gap filling need to be done timely. The data in Table-5 revealed better adoption of gap filling with seeds raised in leaf bags, $2^{\text {nd }}$ weeding and hoeing during $3^{\text {rd }}$ week, removing apical portion of the plant at $1 \mathrm{~m}$ height to promote reproductive branches, as well as drainage to prevent water logging. Adoption of life saving irrigation during dry spell, first weeding and thinning 10-12 days after emergence, and keeping the crop weed-free up to 30-40 days after sowing was not satisfactory and needed improvement. Poor adoption was observed on bunding, levelling, and sub-plotting. In crop management practices that were adopted poorly, the farmers require a better understanding and training through educational approaches by the extension officials promoting cotton cultivation in the two districts.
Cotton crop is affected by diseases such as root rot, fusarium wilt, anthracnose, bacterial blight, leaf spot, and boll rot and by insect pests such as boll worm, jassids, aphids, thrips, white fly, and leaf roller. Integrated insect pest and disease management is recommended and farmers need to go for a minimum of five sprayings. Cotton farmers are generally very concerned about plant protection measures. This might be the reason why the respondents adopted the practices of $1^{\text {st }}$ to $4^{\text {th }}$ spraying as given in Table- 6 . The farmers need to be educated about the $5^{\text {th }}$ spraying after 110 days and spraying with mixtures of both insecticides and fungicides.

Harvesting of cotton is usually done by hand picking and 4-5 pickings are suggested to complete the harvest. As observed in Table-7, adoption of practices was well done for hand picking fully burst open bolls, ploughing of field after harvest to incorporate debris into soil, spreading harvested bolls in sun for 2-4 
hours to dry, uprooting cotton plant after last picking and burying to kill insect pests and disease pathogens, ensuring moisture at boll bursting, and not keeping picked cotton bolls in wet channels in the field that impairs quality. However, deficiencies were observed in picking bolls during the cool hours of morning, avoiding admixture of leaves while picking, initiating picking when $50 \%$ of bolls were bursting, as well as 4-5 pickings within 50 days to complete harvest.

Path analysis was carried out to segregate the total effect of socio-economic attributes of respondents into direct, indirect, and residual effects. It was observed that the attribute extension contact had the highest indirect effect and showed association with five other attributes (Table-8). Hence, the attribute extension contact channelised through house type, economic aptitude, social participation, annual income, and farming experience exhibited significant influence on adoption of recommended practices in cotton crop cultivation. The residual effect of 0.033 inferred that $3.3 \%$ of the variation in this association could not be explained.

In conclusion, cotton is one of the primary economic bases of the people, mostly tribals, in the study districts. The farmers have been cultivating cotton over the years for income generation to support their livelihood. They have accumulated experience because of which they could adopt recommended crop management practices fairly satisfactorily. However, poor adoption of recommended practices was observed in using crop cultivars, sowing in paired rows, drilling two seeds per pit, delinting treatment of seeds, and applying recommended organic manures and chemical fertilisers, particularly based on soil test.

Deficiencies in adoption of recommended practices were also observed in hormone application, $3^{\text {rd }}$ weeding, hoeing and earthingup at 6 weeks, bunding, levelling and subplotting, plant protection measures 110 days after sowing, picking of bolls during the cool hours of morning, picking at $50 \%$ bursting of bolls, and avoiding admixture of leaves at harvest. Socio-economic attributes such as extension contact, type of dwelling, social participation, annual income, farming experience, and economic aptitude significantly influenced proper adoption of crop management practices.

Since cotton was the primary source of income generation for the respondent farmers, the agricultural extension officials promoting cotton cultivation in these districts have to analyse the factors responsible for poor adoption of certain crop management practices and take appropriate approaches to enrich the knowledge and skills of the farmers to enable them to adopt suitable crop management practices to enhance yields and generate more income.

\section{References}

Blaise, D. (2006): Yield, boll distribution and fibre quality of hybrid cotton as influenced by modern method of cultivation, Journal of Agronomy and Crop Science, 192:248-256.

Cetin, O and Basbag, S. (2010): Effects of climatic factors on cotton production in semi-arid region-A review, Research on Crops, 11(3): 785-791.

Gruere, G. and Sengupta, D.(2011): Bt cotton and farmer suicide in India: An evidence based assessment, Journal of Development Studies, 47:316-337.

Padwal, D., Jahanara, Syed, H.M., Bose, D.K. and Srivastava, J.P. (2018): A study on knowledge of $\mathrm{Bt}$ cotton cultivation practices in Rangareddy district of Telengana, Journal of Pharmacognosy and Phytochemistry, 7(3): 2204-2205. 
Rajeswar, J.S., Patange, N.R. and Kadam, S.B. (2019): Extent of adoption of practices by cotton growers for the management of pink boll warm, Trends in Biosciences, 12(3): 246-250.

Salihu, A. and Singh, H.P. (2020). Cotton production and socio-economic characteristics of farmers in Maharashtra, India, Journal of Environmental issues and Agriculture in developing countries, 12(1): 21-29.
Sawan, Z.M. (2009): Response of flower and boll development to climatic factors in Egyptian cotton, Climate Change, 97:553-591.

Sawan, Z.M., Hana, L.I., Gad, E. Karim, Gh.A. and Mc Cuistion, W.L. (2002): Relationship between climatic factors and flowers and boll production in Egyption cotton, Journal of Arid Environment, 52(4) :499-516.

\section{How to cite this article:}

Chitrasena Padhy, Pakalpati Satyanarayana Raju and Rabindra Kumar Raj. 2021. Cotton Crop Management Practices Adopted in a Tribal Region of Odisha. Int.J.Curr.Microbiol.App.Sci. 10(01): 811-819. doi: https://doi.org/10.20546/ijcmas.2021.1001.100 